\title{
Re-Engineering Values Education in Nigerian Schools as Catalyst for National Development
}

\author{
Enu, Donald Bette (Corresponding Author) \\ Department of Curriculum\& Teaching \\ University of Calabar, Calabar \\ E-mail: bette2004@yahoo.com \\ Esu, A. E. O. \\ Department of Curriculum and Teaching \\ University of Calabar, Calabar
}

\begin{abstract}
The decay in the Nigerian society has affected the standard of values and moral character formation. This has manifested in so many anti-social vices. Anti-social behaviour exhibited include corruption, dishonesty, greed, violent crimes, lack of accountability, indiscipline, disrespect to constituted authorities, laziness, low moral courage among many others. All these have constituted a serious moral problem for the Nigerian State and have constrained all sincere efforts targeted at achieving national development. This paper having reviewed the weak values system in Nigeria strongly recommend the re-reengineering of values education in Nigeria schools as catalyst for national development. It is the view of the authors that the pursuit of national development is first attitudinal and so the citizenry should be given new orientation that goes to ensure the overhauling and reconstruction of the total values system in the society for obvious national development to be guaranteed. The authors advocated as a matter of necessity the development and introduction of a national policy on values education as a references instrument which will be used as a realistic paradigm for behavioral transformation and ethical reorientation. This is one sure way of attaining national development
\end{abstract}

Keywords: Re-engineering, Values Education, School, Curriculum, National Development

\section{Introduction}

Nationally and internationally, there is increasing demand from schools in respect of their mandate on the formulation of acceptable values for the young ones to imbibe and live with. This is stem from the rapid decay of the overall values system among nations of the world. The survival of values education becomes imperative because of nostalgia of the past, disappointment of the present and hope for the future generations.

Nigeria is bedeviled with the challenges of not only economic transformation but that of reconstructing and rebuilding the society's values system. The strengthening of the values system provides an enabling platform for a breakthrough the nation's vision 20:20:20. Questions to ask according to National Economic Empowerment and Development Strategy (2004) about Nigeria vision are: what kind of Nigeria do we want for ourselves, for our children, and for the rest of the world? Answers to the above are articulated in the vision 2001 Kuru declaration of NEEDS (2004) which states:

To build a truly great African democratic country, politically united, integrated and stable, economically, prosperous, socially organized with equal opportunity for all and responsibility from all, to become the catalyst of (Africa) Renaissance and making adequate all embracing contributions, sub-regionally, regionally and globally (P:2)

The above pursuit is meant to advance development in Nigeria from all fronts of national endeavours even though Nigeria is a country of paradoxes according to Soludo (2006). This is based on the fact that it is a country abundantly blessed with natural and human resources but in the last four decades of its independence, its potentials have remained largely untapped and the little that has been trapped mismanaged.

The poor condition in Nigeria and the inability of the leaders to provide conditions necessary for national development since independence demand serious concern by those who care about "the Nigeria project". To Dike (2005), the quest for national development in said to bring with it valuable and positive changes that improve the living standards of the people, creates employment opportunities, and reduces poverty, among other things.

Emphasizing further on the need to advance development, Dike (2005) pointed out that economic development increases the efficiency of a system in the production of goods and services to meet the basic needs of the people in 
the society. The attainment of this challenge of self sufficiency is greatly determined by the character and attitude of the leaders who are entrusted with the management of the society. The failure on the part of the leaders fifty years after independence to lay sustain foundation for economic growth and development justifies the necessity for a national rebirth programme directed at ensuring ethical reorientation for the leaders and for the followers who compliment the efforts of the leaders. This is further strengthened by the Federal Government national re-branding effort aimed at building hope and confidence among Nigerians and International community.

The big questions to ask are where lies the problems of Nigeria in terms of achieving the much desired national development? What can be done to address the possible constraints to national development? Are the challenges of national development in Nigeria attitudinal in character or physical in shape? The paper is interested in establishing how values can be re-engineered to create lasting and sustained environment that will stimulate national development in Nigeria.

\section{WHAT ARE THE NIGERIA CORE PUBLIC VALUES?}

It is quite imperative to understand the concept of values before identifying and establishing Nigeria core public values. Bodurin (2009) noted that values are basic beliefs and attitude in a society whether of individual or groups which are considered worthwhile and which serve as guide to choices and behaviour in daily life. Esu (2009) further defined values as ideals that guide or qualify your personal conduct, interaction with others, and involvement in your career. Values help one to and inform one on how he or she can conduct one's life in a meaningful way. On his part, Bolarin (2009) after broad consideration of various definitions of values defined values to mean trait, practices, acts, ideals, beliefs, attitudes, and principles that a group or society considers to be of merit, worthwhile, dear, acceptable and right.

From the above, the core values of Nigeria that have been weakened over the years need to be strengthened for obvious national development to be achieved. NEEDS (2004) described Nigeria as a multi-ethnic society, with a value system that is derived from the diversity of its people, religion and culture. These core values NEEDS identified include respect for elders, honesty and accountability, co-operation, industry, discipline, self-confidence and moral courage.

The above core values are grossly compromised in the present Nigeria socio-economic and political contexts to the extent it this has constituted a serious moral problem. Their excessive compromise has manifested in greed, corruption dishonesty, violent crimes, political killings, drug peddling, and so many other anti-social behaviours capable of jeopardizing all sincere efforts directed at stimulating national development. From this weak background, Dike (2005) calls for the strengthening of values education in schools as corruption drives and shapes social values in Nigeria, and for some individuals the quest for easy money is a justification for violating the laws of the land and distorting official policies directed toward national development. Given this circumstance, the imperative for values education cannot be over emphasized as values education involves educating for character and for good moral values. This implies the teaching of respect and responsible adult life to the citizens. It is for good character and moral development which will lead to a healthy nation.

Basic fundamental moral values every responsible nation should teach its citizens include respect for constituted authority and sanctity of life, responsibility, values of honesty, fairness, tolerance, prudence, self-discipline, helpfulness, compassion, cooperation and courage, along- side some fundamental procedural values look upon as basic ingredients of democracy. They include the rule of law, equality of opportunity, due process, representative government, checks and balances and democratic decision-making. These are the underlying democratic values that guarantee democratic stability.

Nonetheless, Bolarin (2005) went further to identify some dominant values which formed the core values upheld by a larger section of the Nigerian society to include the following:

Detesting laziness

Dignity of labour

Respect for parent/elders

Hospitability

Public spiritedness

Respect for authority

Hard-work

Respect for sanctity of life 
Honesty and truthfulness

The above cherished values radically started getting eroded and to corroborate Aderinwale (2003), the paradigm has shifted and Nigerians have generally slipped away from those cherished core values and embraced a new culture, a new way of life, a new world views. The consequence is that those cherished values have been diluted by the prevailing societal vices.

To Kanu (2005), the core public values of the society were the primary contents of education that constituted child-upbringing and it emphasized development of such attitudes as hard-work, open competition, high achievement orientation and communal cooperativeness. Within this world view, the worth of every individual was measured by the extent to which he/she contributed to the progress and welfare of the society and not by the amount of personal wealth amassed.

Report of a national Framework for Values Education in Australian Schools (2002) identified global education curriculum to have emphasized the development of positive values and attitudes, based on a strong sense of identity and self esteem and encompassing caring for others, recognizing responsibilities, a commitment to upholding the rights dignity of all people and an appreciation of diversity and difference. It also encourages and empowers learners to translate their knowledge, skills and values into a preparedness to participate actively in community life.

\section{Values System Re-Engineering: The Challenge of The Nigerian School System}

The school is a worthy platform for the restoration our cherished values and at the same time used to change our orientation. In support of the above, Bolarin (2005) observed that a look at the curricular for all levels of education indicate that Nigeria cherished the inculcation of social norms, teaching cooperation and team spirit, teaching good habits, character and moral training and the development of sound attitudes. For education involves the transmission of the core values of the society from generation to generation.

The school being an agent of social reproduction and transformation is expected to assist the society in its attempt to socialize the people. It has the responsibility of examining carefully and classifying those values that are permanent to the society. Through its various social programmes in addition to academic, the school should be able to change the orientation of the youths under its care. It is the responsibility of the school to shape the lives of the young ones, and equip them with the right values. By equipping them with the right values, they now become responsible and productive members of the society. Stressing further that without values, men are not human beings and cannot take decisions that can be of benefits to the society.

Indeed values are of significance to national development. Their existence and sustenance constitute a potent force toward the overall growth of the society. From available literature, Bolarin (2009) identified the different types of values to include: moral values, economic values, aesthetic values, religious values, political values intellectual values, cultural values, scientific values and humanistic values. A cumulative impact of all these values if well directed can enhance the national development effort.

But looking at the practical situation of Nigeria in terms of sustainability of the values system, one will be left in no doubt that the challenges are quite enormous. According to Soludo (2006b) Nigeria is a country with decayed value system. And so overcoming the decay of four decades and joining the elite club of developed economies will task the energies of all Nigerians. He identified huge infrastructure deficiencies to fix insecurity of lives and property to solved, address the educational crisis and upgrade our capacity in agriculture. Fundamentally, we need to build a socio-economic and political system that guarantees equal opportunity and voice to all. According to Soludo, all these crises cannot be dealt with in one day; it will take concerted effort or several years to built Nigeria, that Africa superpower.

With this kind of debased values system, it become an issue of national concern according to Bolarin (2009) to the extent that the annual congress of the Nigeria Academy of Education in 2004 issued a communiqué acknowledging the problem of disoriented, displaced and degenerated values in Nigeria system thus:

There is an ethical crisis in our country Nigeria. This manifests itself in such forms as exhibition of negative ethical attitudes such as indiscipline, poor attitude to work, lack of respect for law and order, cheating, drug pushing, engaging in armed robbery, oil bunkering, human trafficking and kidnapping. Above all, there is pervasive lack of moral integrity in business, banking and commerce at home and abroad to such an extent that Nigerians are everywhere usually suspected of cheating, stealing, and fraud especially of the 419 variety.

With particular reference to education, the Congress was appalled at the lack of moral integrity exemplified, for instance, by the pervasiveness of certificate forgery, examination malpractices and the menace of obscene mode of dressing in our educational institutions. 
The single most important index of our national moral debasement is of course corruption which has eaten deep into all facets of our national life. It manifest in different forms: among religious groups, in the judiciary, law enforcement agencies and among the political class.

The big question to ask is given the plethora of challenges, which of course the solution rest with the transformation of human orientation, what can be done to ensure a reversal of this negative situation? This is where values education becomes imperative. It is believed that values and moral development promote critical thinking and moral development. All these impact national development. On the strength of this, Dike (2005) clearly asserted that to prepare for life in a modern society, the citizens should be exposed to qualitative education and acquire good moral values to enable them create human society and to function effectively in the society. Not only the citizens, the leaders should understand that values education do not occur in a vacuum as the leader must plan for it. The challenge to the Nigerian political leaders is to confront the problem with innovative ideas and integrated values education in the nation's school curricula for good character development.

To corroborate the above, Enu (2010) position on values and character education would not have occurred by chance when he strongly noted that the need for character and moral education in Nigeria educational institutions is quite obvious especially when viewed against growing acts of fallen moral values such as stealing, cheating, cultism, examination malpractice, sexual proximity indecent and obscene mode of dressing, act of forgery of certificate to gain admission into higher schools etc. Similarly, Ewa (2003) had previously submitted that character and values education are inescapable mission of schools. The goal of which is to help children develop good dispositions that will enable them to flourish intellectually, personally and socially. This made Bohliha (2001) to agree that with intentional, thoughtful character and values education, schools can become communities in which virtues such as responsibility, hard-work, honesty and kindness are taught and respect celebrated and continually practiced.

From the above mandate of the school, it is convincing that the school system in seen as an agent of change and social reproduction which is in consonance with Section $1(1, a)$ of FRN (2005). This section provided that education shall continue to be highly rated in the national development plan because education is the most important instrument of change; any fundamental change in the intellectual and social outlook of any society has to be proceeded by an educational revolution. In line therefore with the above provision values education must be strengthened as a radical paradigm shift which should be considered as an intervention of system re-branding. This will provide a solid background for practical actions in creating an enabling environment for moving towards a world class-status (Obanya, 2010). This in our thinking can be followed up with a sustained national policy on core public values in Nigeria. The successful implementation and internationalization of public values has to be guided by a national policy that addresses burning issues that are capable of consolidating national development. The advocated national policy on values education and character formation should be seen as a catalyst for re-branding Nigeria where all the negative values are reversed and ensure the enthronement of enabling values of caring, well governed society where justice and equity reigns

\section{Values Education and National Development}

The quest for national development in Nigeria has been an issue of great concern to all who have a stake in the existence of an entity call Nigeria. In search of genuine national development, a lot of development agenda, programmes and reform measures have been initiated and implemented by both government and development partners.

Being a country of paradoxes, it is blessed abundantly with natural and human resources, whose potentials according to Soludo (2006a) have remained largely untapped and the little that have been tapped mismanaged. This becomes the major problem of attaining national development. To break through requires proper economic planning which to Ndebio (1997) is basic to the attainment of economic growth and development. This becomes all the more imperative because the pursuit of economic development after the Second World War has been crystallized by the universal acceptance of development planning. This is regarded as the surest and most direct route to economic progress (Todaro, 1977).

Furthermore, Obanya (2010) identified national strategic planning which provides practical tools for ensuring that policies really make positive impact. Such national strategic plan must take a holistic view of issues. This implies dealing with the root cause of issues; not simply their surface manifestations. Such plans often take a long term perspective view of issues though it may include medium term sub-phases. Obanya submitted that a strategic plan does not address all possible challenges. It rather limits itself to issues of strategic importance, issues that do impact on a lot of related issues. Issues are prioritized with emphasis on higher impact areas.

Arising from the weak socio-economic and political development of Nigeria 50 years after independence flow various forms of challenges manifested from different fronts. They ranging from infrastructure deficiency, insecurity 
of lives and property, unemployment, poverty reduction, improved agricultural productivity promoting private enterprise, improve the quality of education; add creditability to leadership and changing the way of governance among others. To break the barriers and joining the elites club of developed economies is a no mean task. According NEEDS (2004) since the transition to democracy in1999, Nigeria has laid a solid foundation for economic growth and development. Nigeria is richly endowed with huge human and material resources that give it the potential to become Africa's largest economy and a major player in the global economy. But the inability to manage the resources occasioned by poor leadership is likely to jeopardize all efforts directed at ensuring the attainment of the Millennium Development Goal by 2015.

In Nigeria today, considering the enormous challenges of socio-economic and political transformation traceable to decayed values system to attain national development, the overall values system need to be re-engineered to instill the virtues of patriotism and true national identity in the minds of the citizens who are the vanguard of national development. But where the values system is weak and totally debased as it is in Nigeria, the internal commitment to build a true nation state becomes doubtful. The strength of values is in the fact that they build character and this produces behaviour that is beneficial to the individuals, others and the community. Values enhance the wellbeing of all; prevent harm to both the individuals and the society: they are the essence of healthy relationships and are essential for the conduct and preservation of a democratic society (Ewa, 2003).

When the government and the people are committed to the moral foundations of democracy, they tend to respect the rights of others, respect the laws, they are concerned with the common good and will have regard for truth and justice. Supporting the above, Esu(2009) writing on humanistic values made reference to the North American council for Humanism $(\mathrm{NACH}, 2000)$ that:

Humanistic values of the 21 st century must be secular, democratic and pluralistic: the values must be of the people for the people and by the people. They must embrace common moral decencies such as altruism, integrity, freedom, justice, honesty, truthfulness, responsibility, compassion, and must reflect the normative standards human beings discovered and developed through living together.

Humanistic education is essential for preparing young people to be good citizens in a democracy. If democracy is to work, its citizens must be educated. They must know how to gather information, distinguished facts from opinion, analyze issues, understand many different viewpoints, understand justice, think for themselves, communicate their opinions clearly and work with others for common good. These are among the most important skills that humanistic education seeks to teach our youths. For this reason, political education becomes an important aspect of humanistic values education where honesty is playing the game of politics, integrity in holding public office is taught to the youths. The above becomes essential components of good nation building where national development is guaranteed.

The above no doubt will stimulate trust in governance as these democratic values are seen as facilitators of true national development. Even though NEEDS (2005) in its vision statement wish to create a new Nigeria where all the negative values in our society are reversed and in their places established enabling values of caring, well-governed society where justice and equity reigns. However, when Enu (2010) examined the above in line with what is tenable in Nigeria. The practical situation reveals that Nigeria as a society is highly defective in governance, institutional structure, moral integrity, honesty and truthfulness. Also the country is defective in justice system, consideration for others, culture and indeed in educational values. Enu further opined that if values are accepted as mechanism or framework by which we carry out assessment of ourselves, surrounding, our actions and events and based on the situation take action and decisions about our state of being, and the state of the nation and world at large, then the situation in Nigeria is nothing short of total collapse of our overall values system. Based on the above, the author submitted that moral values are compromised through greed, sycophancy, mediocrity, corruption, insecurity, official high handed ness, obnoxious policies for the benefits of the few, religious intolerance among others. NEEDS (2004) call for a strategy that hopes to lay a solid foundation for national rediscovery and strong values based on:

Enterprise, competition and efficiency at all levels

Equity and care for the weak and vulnerable

Moral rectitude respect for traditional values and pride in Nigeria culture

A value system in public service that result in efficient and effective service delivery to the citizens and

Discipline at all levels of leadership (p:4).

The above strongly indicate a reconstruction of the total values system of Nigeria which may be through the instrumentality of education. This therefore is in line with Kanu (2005) constructionist approach to the school curriculum and values education. Kanu referred to reconstructionism as an educational doctrine which emerged out 
of the quest for strategies that the school could adopt to significantly influence progressive change in all cultural contexts. It is predicated on a demonstrable power of culture in determining adaptation to change. Since the school and other allied social institutions of education has the capacity and needs to facilitate, promote and possibly guide certain forms of value change in the society. This re-constructionist approach becomes the ideal education strategy that can bolster and sustain the basic public core values in the present Nigeria. When these values are properly reestablished, and the entire citizenry given a new orientation, the drive to pursue national development would have been guaranteed.

\section{Summary and Recommendations}

Looking at the socio-economic and political landscape of Nigeria, and in consideration of the prevailing societal order, this paper attempted to establish the relevance of values education as catalyst for national development. The challenge of attaining national development is seen to be attitudinal in character and in form.

This paper identified Nigeria as one blessed entity full of excellent potentials both material and human but with a weak values system, the leadership has not been able to harness the resources to stimulate national development. The absence of core public values such as respect for elders and constituted authorities, honesty, accountability, cooperation, industry alongside discipline, self-confidence and moral courage have gone a long way to fertilize social vices such as corruption, greed, dishonesty, mediocrity, intolerance, and many others. All these have change the nation values system, a situation which has led to a strong moral problem. The paper strongly advocated for the strengthening of values education as a possible paradigm for behaviour transformation and ethical reorientation. It is also the authors view that a national policy on values education be put in place as a reference instrument that will guide both individual and official transactions in the country. When all these are sustained, the possibility of attaining national development is assured.

\section{References}

Aderinwale, A. (2003). Value, Ideology and Nation Building. 15th Distinguished ledure series. Aderiran Ogunsanya College of Education, Ijanikin Lagos.

Bodunrin, P. O. (2009). Unpublished Postgraduate Seminar Paper, Faculty of Education, Lagos State University.

Bohliha F. R. (2001). Building Character in Schools: Resources Guide-an expcert from chapter 2. centre for the Advancement of Ethics and character.

Bolarin, T. A. (2005). Education as agent of Value Clarification and Orientation. In Values Education. Proceedings of the 19th annual congress of the academic of education held at the Lagos State University, Lagos, 22nd-26th November, 2004.

Bolarin, T. A. (2009). Values disorientation in the Nigerian system. In Ivowi, U. M. O. (Ed) Education. for Value Lagos: The CIBN press limited.

Danladi, E. N. (2005). Attitude and Values for self-reliance and progress in a democratic setting. In Values Education. proceedings of the 19th annual congress of the academy of education held at the Lagos state University, Lagos, 22nd-26th November, 2004.

Dike, V. E. (2005). Values Education and National Development file: IIC Documents and setting /user/desktop/values-education-and-natural development.html.25/2/2010.

Enu, D. B. (2010). Selected Issues in Global Education. Calabar Essinej Printers.

Esu, A. E. O. (2009). Education for Humanistic Values. In Ivowi, U. M. O. (Ed) Education for Value. Lagos: The CIBN Press Limited.

Ewa, A. O. (2003). The role of the Teacher in the moral atmosphere of the school. Unpublished M.Ed seminar paper submitted to the Department of Curriculum an Teaching, University of Calabar.

Federal republic of Nigeria. (2004). National Economic Empowerment and Development Strategy (NEEDS). Abuja. Perfect Printers Limited.

Federal Republic of Nigeria. (2005). National Policy on Education Federal NERDC Yaba Lagos-Nigeria.

Kanu, O. R. (2005). The School Curriculum and Values Education in the Nigeria Context: A Reconstructionist Approach. In Values Education. Proceedings of the 19th annual congress of the academy of education held at the Lagos state university, Lagos, 22nd-26th November, 2004.

NACH. (2000). North American Council for Humanism. 
Ndebio, J. E. U. (1997). Strategies for better socio-economic management in K. M. Ogon Etta (Ed). Nigeria's Ultimate Goals: The Journey so far Calabar: Ushie Printers (Nig) Ltd.

Obanya, P. (2010). System re-engineering and institutional rebranding for building a world class university: the Nigerian perspective. 4th Annual lecturer of Grace Mbipom foundation Delivered at the University of Calabar Hotel Conference hall, Calabar-Nigeria on June 1st 2010.

Report of National Framework for values education in Australia Schools (2000). Global perspectives: A Framework for Global Education in Australian Schools. Http://www.valueseducationedu.au/values. 20/5/2010.

Soludo, C. C. (2006a). Law Institutions and Nigerian Quest to join the first world economy. Lecture delivered in honour of the retired justice of the supreme Courte of Nigeria, Justice Kayode Eso, at the Obafemi Awolowo University, le-Ife on July 25, 2006.

Soludo, C. C. (2006b). Can Nigeria be the China of Africa? Lecture Delivered at the founders day of the University of Benin, Benin City Nigeria on November 23, 2006.

Todaro, M. P. (1977). Economic development in the Third World. London: Longman Group Limited. 